\title{
Follow up after sample size re-estimation in a breast cancer trial for time to recurrence
}

\author{
Erinn Hade ${ }^{3,1^{*}}$, Gregory Young ${ }^{1}$, David Jarjoura ${ }^{4}$, Richard Love ${ }^{2}$ \\ From 2nd Clinical Trials Methodology Conference: Methodology Matters \\ Edinburgh, UK. 18-19 November 2013
}

In an international trial of premenopausal women with hormone receptor positive operable breast cancer that compares how the timing of surgical oophorectomy and mastectomy affects time to recurrence, we re-evaluated the required sample size near the end of the planned accrual period. We had anticipated that failure probabilities used at the design stage were too high resulting in a loss of power for the hazard ratio of interest. Extending follow up to obtain the number of events expected during the initial planning was not a viable option due to evidence in several previous trials of converging hazard functions. We proceeded to develop a method to re-estimate sample size in this time to event trial based on the blinded trial. Blinded re-estimation was our preference since we did not want to risk the perception that the sample size was manipulated because a smaller effect, than was anticipated, was found. Using data from a previous trial in a similar patient population receiving the same therapy (but who were not randomized to surgery timing) and the current blinded trial data, we reestimated the required sample size. The distribution of bootstrap re-estimates of sample size indicated no increase in sample size was needed for the proposed HR. Follow-up for this trial is now complete. We will examine the final failure rates and hazard functions to see how well our re-estimation procedure performed. We will be able to explore if the hazard functions converged dramatically and what this impact would have been without this consideration.

\section{Authors' details}

${ }^{1}$ The Ohio State University, Columbus, OH, USA. ${ }^{2}$ The International Breast Cancer Foundation, Madison, WI, USA. ${ }^{3}$ University of Edinburgh, Edinburgh Clinical Trials Unit, Edinburgh, UK. ${ }^{4}$ none, NC, USA.

${ }^{3}$ University of Edinburgh, Edinburgh Clinical Trials Unit, Edinburgh, UK Full list of author information is available at the end of the article
Published: 29 November 2013

doi:10.1186/1745-6215-14-S1-0107

Cite this article as: Hade et al: Follow up after sample size reestimation in a breast cancer trial for time to recurrence. Trials 2013 14(Suppl 1):0107.
Submit your next manuscript to BioMed Central and take full advantage of:

- Convenient online submission

- Thorough peer review

- No space constraints or color figure charges

- Immediate publication on acceptance

- Inclusion in PubMed, CAS, Scopus and Google Scholar

- Research which is freely available for redistribution

Submit your manuscript at www.biomedcentral.com/submit
C Biomed Central 